\title{
Correction to: Mast cell proliferation in the cerebrospinal fluid after intraventricular administration of anti-B7H3 immunotherapy
}

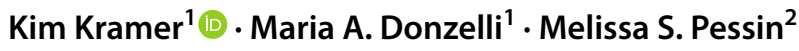

Published online: 30 April 2021

(c) The Author(s) 2021

\section{Correction to: Cancer Immunology, Immunotherapy https://doi.org/10.1007/s00262-020-02824-0}

Publisher's Note Springer Nature remains neutral with regard to

The original version of this article unfortunately contained a mistake. NCT number is incorrect. The correct number is NCT03275402.

In section "Case presentation", first sentence of the second paragraph should read as

The patient underwent treatment according to Memorial Sloan Kettering Cancer Center salvage regimen consisting of craniospinal radiation therapy, chemotherapy and intraventricular ${ }^{131}$ I-omburtamab on a phase 2 IRB-approved protocol (NCT03275402) [1].

Ethics approval section should read as

Patient (proxy) consented to be treated on IRB approved protocol registered to clinicaltrials.gov NCT03275402.

Open Access This article is licensed under a Creative Commons Attribution 4.0 International License, which permits use, sharing, adaptation, distribution and reproduction in any medium or format, as long as you give appropriate credit to the original author(s) and the source, provide a link to the Creative Commons licence, and indicate if changes were made. The images or other third party material in this article are included in the article's Creative Commons licence, unless indicated otherwise in a credit line to the material. If material is not included in the article's Creative Commons licence and your intended use is not permitted by statutory regulation or exceeds the permitted use, you will need to obtain permission directly from the copyright holder. To view a copy of this licence, visit http://creativecommons.org/licenses/by/4.0/.

The original article can be found online at https://doi.org/10.1007/ s00262-020-02824-0.

Kim Kramer

kramerk@mskcc.org

1 Department of Pediatrics, Memorial Sloan Kettering Cancer

Center, 1275 York Avenue, New York, NY 10065, USA

2 Laboratory Medicine, Memorial Sloan Kettering Cancer Center, 1275 York Avenue, New York, NY 10065, USA 